\title{
Inventory of Invasive Plant Species along the corridor of Kawah ljen Nature Tourism Park, Banyuwangi, East Java
}

\author{
Lia Hapsari ${ }^{1.2}$, Abdul Basith ${ }^{1}$, Hari Rusdwi Novitasiah ${ }^{1}$ \\ ${ }^{1}$ Magister Program in Biology, Faculty of Mathematic and Natural Sciences, University of Brawijaya, Malang, East Java, \\ Indonesia \\ ${ }^{2}$ Purwodadi Botanic Garden - Indonesian Institute of Sciences, Pasuruan, East Java, Indonesia
}

\begin{abstract}
A field survey was conducted in November 2013 to inventory invasive plant species present along the corridor of Kawah Ijen Nature Tourism Park exploratively. Result showed that there were 11 plant species found abundantly along the corridor. Typical native species were dominated by Cyathea contaminans, Casuarina junghuhniana and Vaccinium varingiaefolium. Three species were determined as invasive alien species i.e. Chromolaena odorata, Acacia decurrens and Blumea lacera whereas five species were determined as native species but potential invaders i.e. Rubus moluccanus, Melastoma malabatrichum, Polygonum barbatum, Debregeasia longifolia and Pteridium aquilinum. In term of tourism particularly on nature-based destinations enable moving in and out of invasive alien species due to opening the access of some natural protected areas. The environmental impact of an alien species whether it becomes invasive at its destination depends on its biological key point, what ecological role the species may play, and on additional factors such as its tolerance of the gross features of the environment in the new range.
\end{abstract}

Keywords: invasive plants, corridor, Kawah ljen, Nature Tourism Park, Banyuwangi

\section{INTRODUCTION}

Indonesia is an archipelago located in South-East Asia region comprising approximately 17,508 islands with $1,860,359.67 \mathrm{~km}^{2}$ of terrestrial area, 5.8 million water area $\mathrm{km}^{2}$ and of $81,000 \mathrm{~km}$ coastal line. The country has abundant natural resources as a result of the upheaval of Asian and Australian plates that suggest high level of biodiversity which support as the world's second mega-biodiversity country after Brazil. Indonesia is not only rich in genetic and species diversity, but it is also rich in ecosystem diversity, which includes natural diversity of the terrestrial landscape as well as water, in which organisms (plants, animals and micro organisms) interact with their physical environment [1,2]. Furthermore Indonesia consists of hundreds of distinct native ethnic and linguistic groups which forms very plural cultural diversity [3]. This natural resources and cultural diversity are play vital role as capitals for national development, in which one of approach is through ecotourism.

Ecotourism has become one of the fastgrowing sectors of the tourism industry, growing annually by $10-15 \%$ worldwide. Ecotourism is defined as "responsible travel to natural areas that conserves the environment and improves

Corresponding Address:

Email : lia.hapsari@lipi.go.id

Address : Jl. Surabaya - Malang KM 65, Pasuruan, East Java 67163 , Indonesia the well-being of local people" [4]. Ecotourism attractions in Indonesia is dominated by naturebased $(60 \%)$ and traditional culture $(40 \%)[3,5]$. Ecotourism focuses on socially responsible travel, personal growth, and environmental sustainability; intended as a low-impact and often small scale alternative to standard commercial (mass) tourism [6].

The fact that ecotourism activities give positive impacts but it is also generate negative impacts on natural environment, as well as to the local socio-cultural values. The negative impacts emerged from various aspects including physical, biological, economic, social, cultural and political aspects. Spesific to the environment impacts may occur in form of unexpected changes of environmental which may lead to environmental pollution or environmental degradation including landscapes, vegetation community structure, wildlife, coral reefs and piled of garbages $[3,7]$.

One of threats to biodiversity and environment is invasive species. Introduction, distribution and uses of alien species, intentional or unintentional, have caused ecological losses and considerable economical losses. Environment damage caused by invasive alien species is very difficult to recover because this is related to organisms that perform adaptation, growth and reproduction, it can cause the losses of endemic species. The means and routes by which they are introduced are called invasion 
"pathways". Some non-native species, intentionally introduced for beneficial purposes, later turn out to be invasive. Global trade has enabled modern societies to benefit from the unprecedented movement and establishment of species around the world, it gives access to greater share of biological diversity $[1,7,8,9]$.

Such movement like tourism also become one of ways to introduce and spread the species wider. In term of ecotourism particularly on nature-based destinations enable moving in and out of invasive alien species due to opening the access of some natural protected areas. Ecotourists should be very caring towards environmental sustainability but somehow they can facilitate the spread of invasive species. With some 650 million people crossing international borders as tourists every year, the opportunities for them to serve as vectors for invasive alien species is profound and increasing. They can intentionally carry living plants that eventually become invasive. They can return home with fruits and other living plant materials that carry with them potentially invasive insects parasites and diseases between countries $[1,7,8,9,10]$.

Some researches reported that naturebased tourist destination in Indonesia has been threatened by invasive plant species $[10,11]$. Tourists unwittingly introduce alien plants into national parks, wildlife destination, nature reserve, nature tourism park, etc; where they degrade protected ecosystems and drive up management costs. However, studies on inventory of plant invasive species in naturebased tourist destinations are need to conduct as initial information for decision-making in further conservation efforts. The aim of this study were to inventory and characterize the invasive plant species along the corridor of Kawah Ijen Nature Tourism Park, Banyuwangi, East Java and review its morphological characteristics.

\section{METHODS}

Study area

The field study was done in Kawah ljen Nature Tourism Park, Banyuwangi East Java, Indonesia ( $8^{\circ} 2^{\prime} 30^{\prime \prime}-8^{\circ} 5^{\prime} 30^{\prime \prime} \mathrm{S}, 114^{\circ} 12^{\prime} 30^{\prime \prime}$ $114^{\circ} 16^{\prime} 30^{\prime \prime} \mathrm{E}$ ) (Figure 1). Geographically Kawah Ijen Nature Tourism Park is located in the middle area of Kawah Ijen Merapi Ungup-Ungup Nature Reserve. Administratively governed within two regions of Banyuwangi and Bondowoso. Ijen Mountain Forest area designated as a Nature Reserve by the Decree of the Governor General of the Dutch East Indies No. 46 in October 9,
1920 Stbl. No. 736, with area covers 2,560 ha. In further developments, by the Decree of the Minister of Agriculture in Desember 10, 1981, No.1017/Kpts-II/Um/12/1981 assigns a portion of Kawah Ijen Nature Reserve about 92 ha area containing of the crater lake was declared as Nature Tourism Park, while the remaining area of 2,468 ha remain as a Nature Reserve. Today its management is carried out under The Natural Resources Conservation Center (BKSDA) of Forestry Ministry, Region V, Banyuwangi, East Java [12].

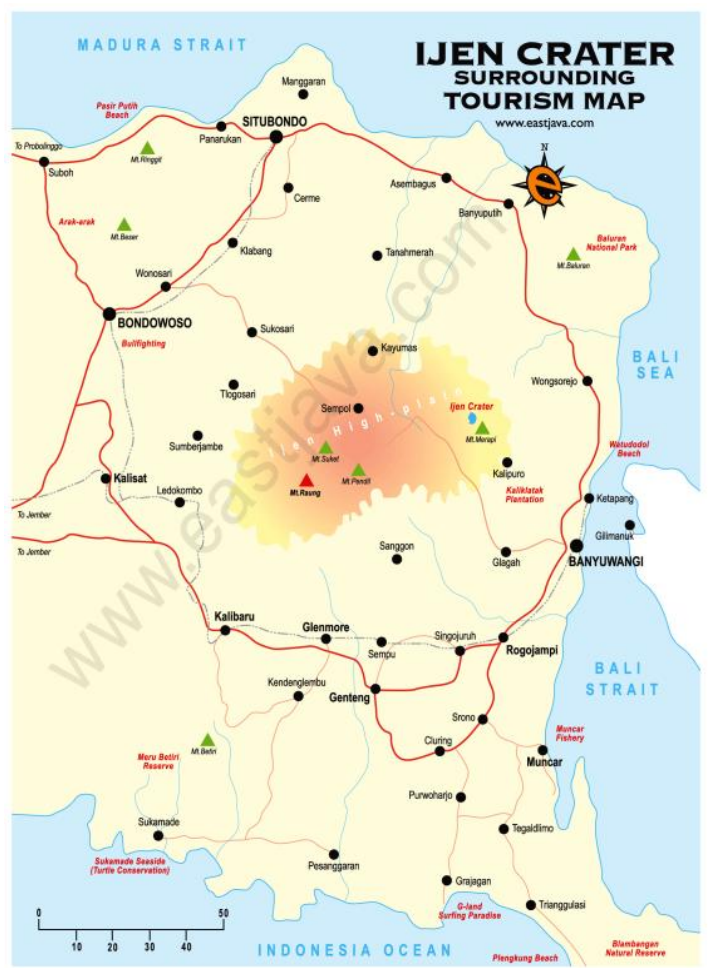

Figure 1. Map of Kawah ljen Nature Tourism Park and surroundings [13].

The corridor of Kawah Ijen Nature Tourism Park were started from PHKA (Forest Protection and Nature Conservation) post at Paltuding (1600 $\mathrm{m}$ above sea level) to the crater lake $(2,346 \mathrm{~m}$ above sea level) about 3 kilometers ( 1.86 miles) long with gradients of 45 to 60 degrees (Figure 2.a). The area is affected by monsoons so that the climate is dry with an annual rainfall average 1500 to $3000 \mathrm{~mm}$ and temperatures -2 to $23{ }^{\circ} \mathrm{C}$ [12]. Due to sulfuric acid from the crater therefore the soils and waters arround the site remained acidic [14].

The ljen volcano complex consists of a group of stratovolcanoes constructed within the $15-\mathrm{km}$ wide ljen caldera. Kawah ljen is an active 
stratovolcano located on the rim of the caldera, which contains a turquoise coloured lake. It is one of the world's largest (30-40 x $106 \mathrm{m3}$ ) natural reservoirs of extremely acidic $(\mathrm{pH}<0.3)$ volcanic water and has a surface area of about $1,000 \times 600 \mathrm{~m}$ and a maximum depth of $180 \mathrm{~m}$. The lake forms a potential danger in the case of an eruption and the area is designated a volcanic hazard. An active vent at the edge of the lake is a source of elemental sulfur, and supports a mining operation [12, 14,15].

\section{Methods}

A field survey was conducted in November 2013 to inventory invasive plant species present along the corridor of Kawah Ijen Nature Tourism Park exploratively. Abundant plant species present on site were also recorded (grasses were excluded). Direct identification were subjected to recognize well-known species. Unidentified species were collected in form of voucher specimens for further identification in Purwodadi Botanic Garden-Indonesian Institute of Sciences, Pasuruan. Literature reviews from plant identification books and many sources such as Flora of Java [16], Plant Resources of South-East Asia (PROSEA) [17], Flora of China [18], Global Biodiversity Information Facility (GBIF) [19], plant databases of botanic gardens, etc. were used to identify and characterize the observed plant specimens.

The plant invasiveness were determine using literature list of invasive plant species [8], also checked in invasive alien plant species database of SEAMEO Biotrop and the State Ministry of the Environment [20] and some world's invasive alien plant species databases including ISSG - The Invasive Species Specialist Group [21], ISC - Invassive Species Compendium [22], Germplasm Resources Information Network (GRIN) - United States Department of Agriculture [23], etc; also from literature reviews.

\section{RESULTS AND DISCUSSIONS}

Inventory result showed that there are 11 plant species found abundantly along the corridor of Kawah ljen Nature Tourism Park (Table 1). Typical native species such as Cyathea contaminans, Casuarina junghuhniana and Vaccinium varingiaefolium were found abundantly in the area at high altitude. Cyathea contaminans (local name: Paku Tiang) were found at lower altitude, widespread in forest/corridor opening then rarely found at higher altitude. Casuarina junghuhniana (Local name: Cemara Gunung) grows naturally on the slopes of volcanoes and also widespread cultivated to all over Indonesia [16]. Vaccinium varingiaefolium (Local name: Delima Manda) commonly found in 1800 to 3340 m.asl $[16,20,24]$. In Kawah Ijen corridor it found only at elevations above of $2000 \mathrm{~m}$ a.s.l. Both plants are typical and dominated in the shift of High Montane Rain Forest and Sub Alpin Forest. Edelweiss (Anaphalis javanicum) were reported abundant in Kawah Ijen [12, 25].

Three species were determined as invasive alien species i.e. Chromolaena odorata, Acacia decurrens and Blumea lacera (Table 1).

Chromolaena odorata (L.) R. M. King \& H. Rob. Syn. of Eupatorium odoratum L (Figure 2.b). Local names e.g. Bitterbush, Butterfly-weed, Christmasbush, Devilweed, Hagonoy, Jack-in-thebush, Paraffin-weed, Siamweed, Triffidweed (English), Fei ji cao (Chinese), Rumput belalang, Rumput golkar, Rumput putih (Malesia). It is native to Northern America, South America and Central America. It has been introduced, naturalized and cultivated to Africa; AsiaTemperate (China, Taiwan); Asia-Tropical (India, Cambodia, Thailand, Vietnam, Indonesia, Malaysia, Papua New Guinea, Philippines), Australasia and the Pasific. Chromolaena odorata is an herbaceous perennial shrub that forms dense tangled bushes $1.5-2.0 \mathrm{~m}$ in height, sometimes reaches up to $6 \mathrm{~m}$ as a climber on other plants. Its stems branch freely, velvetypubescent with lateral branches developing in pairs from the axillary buds. Older stems are brown and woody near the base; tips and young shoots are green and succulent. Flowerheads are terminally corymbs of 20 to 60 heads on all stems and branches. Flowers color are white or pale bluish-lilac, and form masses covering the whole surface of the bush. Seeds are small; $3-5 \mathrm{~mm}$ long, $\pm 1 \mathrm{~mm}$ wide, and weigh about $2.5 \mathrm{mg}$ per seed; it wide dispersed by wind. Chromolaena odorata has been nominated as among 100 of the "World's Worst" invaders. It is reported to interfere with natural ecosystem processes in many national parks. It is a fast-growing shrub, an aggressive competitor and may have allelopathic effects, it forms dense stands that prevent the establishment of other plant species $[8,18,20,21,22,23,17,26]$.

Acacia decurrens Willd (Figure 2.c). Local names e.g. Black wattle, Green wattle, Queen wattle, Sidney green wattle (English); Xian ye jin he huan (Chinese); Acacia noir (French), Schwarze Akazie (German). It is native to - 
Table 1. List of plant species abundantly found along the corridor of Kawah ljen Nature Tourism Park

\begin{tabular}{llllll}
\hline No. & Species & Family & Habitus & Locality & Invasiveness \\
\hline 1 & Chromolaena odorata & Asteraceae & Shrub & Alien & Invasive \\
2 & Acacia decurrens & Fabacceae & Shrub to small tree & Alien & Invasive \\
3 & Blumea lacera & Asteraceae & Shrub & Alien & Invasive \\
4 & Rubus moluccanus & Rosaceae & Shrub & Native & Potential invasive \\
5 & Melastoma malabatrichum & Melastomaceae & Shrub to small tree & Native & Potential invasive \\
6 & Polygonum barbatum & Polygonaceae & Shrub & Native & Potential invasive \\
7 & Debregeasia longifolia & Urticaceae & Shrub to small tree & Native & Potential invasive \\
8 & Pteridium aquilinum & Dennstaedtiaceae & Rhizomes fern & Native & Potential invasive \\
9 & Cyathea contaminans & Cyatheaceae & Tree fern & Native & - \\
10 & Casuarina junghuhniana & Casuarinaceae & Tree & Native & - \\
11 & Vaccinium varingiaefolium & Ericaceae & Shrub to small tree & Native & - \\
\hline
\end{tabular}

Australasia (Australia - New South Wales, Victoria). It has been introduced, naturalized and cultivated to Africa (Ethiopia, Tanzania, South Africa), Asia-Tropical (India, Sri Lanka, Indonesia, Philippines), Asia-Temperate (China), New Zealand, Southern America (Brazil, Caribbean), Northern America (US-California). Acasia decurrens is perennial shrub to small tree 3-10 m high or sometimes taller; bark smooth to deeply fissured, brown or dark grey to blackish; branchlets angled with winged ridges which are decurrent with the petioles. Leaves biparripinates with petiole $0.7-2.8 \mathrm{~cm}$ long, rachis $2-12 \mathrm{~cm}$ long, pinnae 3-13 pairs, mostly 4-7 cm. Inflorescences in axillary and terminal panicles and/or racemes; peduncles 2-5 $\mathrm{mm}$ long, glabrous or hairy; heads globose, 20-32flowered, 4-7 $\mathrm{mm}$ diam. in yellow to bright yellow colour. Seeds in pod; pods straight to slightly curved, flat, straight-sided to irregularly and mostly slightly constricted between seeds, 2$10.5 \mathrm{~cm}$ long, 5-8.5 mm wide, thinly leathery, glabrous. Acacia decurrens first introduced for its fiber in paper production, charcoal for fuels, tannin/dyestuff materials, as road side trees or shade/shelter trees. Then it has become a serious weed problem as it spreads rapidly via seeds and root suckers, and the development of dense thickets has negative consequences for native biodiversity and obstructs water flow $[8,18,20,21,22,27,28]$.

Blumea lacera (Burm. f.) DC. Local names e.g. Malay blumea, Rabbi weed (English), Jian shuang huang (Chinese), Kukronda (India). It is native to Asia-Temperate (China, Japan, Taiwan) and Asia-Tropical (India, Nepal, Sri Lanka,Laos, Myanmar, Thailand, Vietnam, Malaysia, Papua New Guinea, Philippines) and Australasia. It has been widely naturalized to all over Asia, Australasia and the Pacific. It commonly found in dry fields, grasslands, roadsides and forest margins. Blumea lacera is annual or biennial herb, erect, $20-100 \mathrm{~cm}$ tall, slender, very varible weeds with strong champour odour. Stems simple or more often branched, covered with silky hairs or glandular trichomes; branches sometimes ascending. Leaves sessile or petiolate, elliptic to oblong, $10-12 \times 3.5-4.5 \mathrm{~cm}$, veins $5-8$ pairs, pubescent. There are many flower heads in single plant, arranged in axillary cymes or terminal panicle. Fruits achenes oblong, sparsely hirsute; wide dspersed by wind. Blumea lacera is actually edible plant for vegetable with medicinal properties and as ornamental plants but mostly as weeds in open terrains and having allelopathic effects to surroundings $[8,16,18,20,21,22,29]$.

Five species were determined as native species but potential invaders i.e. Rubus moluccanus, Melastoma malabatrichum, Polygonum barbatum, Debregeasia longifolia and Pteridium aquilinum (Table 1). They are mostly typical of plants succession, which have welladaptability to harsh environments, after fire, acidic water and soil, etc., so that become dominant in the area. In some countries it has been declared as invasive species, and even in countries where its native it can be invasive.

Rubus moluccanus L. Syn of Rubus capricorni, Rubus hillii, Rubus moluccanus var. dendrocharis. Local names e.g. Molucca bramble, Molucca raspberry, Queensland bramble, Wild raspberry (English). It is native to moist eucalyptus forest and rainforest of eastern Australia; wide distributed from Queensland to Victoria, through out Asia-Tropical (India, Sri Lanka, Laos, Myanmar, Thailand, Vietnam, 


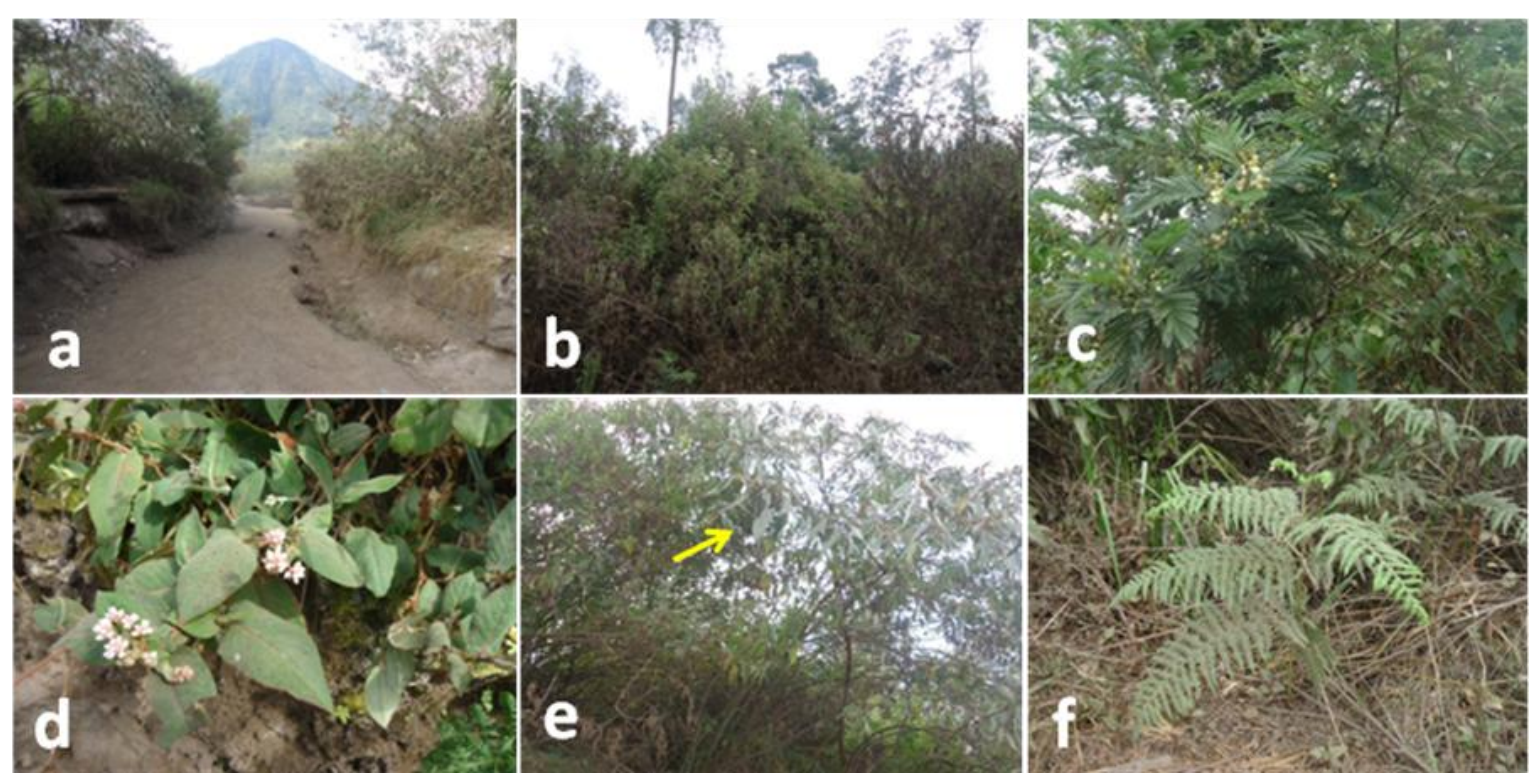

Figure 2. Site documentation (a) Landscape corridor of Kawah ljen Nature Tourism Park; Plant species documentations: (b) Chromolaena odorata, (c) Acasia decurrens, (d) Polygonum barbatum, (e) Debregeasia longifolia and (f) Pteridium aquilinum

Indonesia, Malaysia, Papua New Guine, Philippines) and The Pasifics. Rubus moluccanus is a scrambling shrub or climber reaching 2 to $3 \mathrm{~m}$ high, a member of the raspberry and blackberry family. Stems and leaves are armed with medium sized spines. Leaves are large 2-15 cm long, and 3-10 cm wide and lobed with 3-5 lobes, glabrous or sparsely hairy above, densely white or rusty hairy below. Flowers are pinkish red or white and borne in clusters. Berries are red and about $1 \mathrm{~cm}$ in diameter. Rubus molucanus can spread via runners that sprout when they touch the ground and its seeds are dispersed by birds. This scrambling shrub or climber may threatens native plants through overcrowding and competition and its prickly stems may pose a hazard to humans and livestock. It's declared as aquatic or terrestrial noxious weed, spreading by long arching spiny stems, rooting at their tips, as well as by bird-dispersed seeds. Its berries fruit and leaves are edible, used for culinary purposes and contain of any medicinal properties $[20,21,22,23,30]$

Melastoma malabatrichum L. Local names e.g. Malabar melastome (English), Harendong, Kluruk, Senggani (Indonesia), Senduduk, Sekeduduk, Kenduduk (Malay), Yagomyum (Cebu, Phillipines), Karali (India). It is native to tropical and temperate Asia and the Pacifics and then widespreads throughout the tropics, it can be found in the Indian Ocean Islands, throughout South and South-East Asia, China, Taiwan, Australia, and the South Pacific Ocean; commonly found in the lowland and mountain forests, chiefly in open places, cleared land, waste places and roadside. Melastoma malabatrichum is a shrub to small trees average height of $0.5-1 \mathrm{~m}$ high but may occasionally grow up to $5 \mathrm{~m}$. Stems reddish, covered with small rough scales. Branchlets are numerous, densely covered with appressed scales. Leaves are blade ovate, elliptic, or elliptic-lanceolate, $4-14 \times 1.7-$ $3.5(-6) \mathrm{cm}$, stiffly papery. Inflorescences subcapitate corymbose, terminal, 3-7-flowered, with 2 leaflike bracts at base. Flowers; five petals reddish purple or magenta with five yellow anthers. Fruits are berries, urceolate-globular, 6$15 \times 6-12 \mathrm{~mm}$, succulent, when ripe they break open irregularly to reveal the soft, dark purple, sweet but rather astringent-tasting pulp and numerous orange seed. Melastoma malabatrichum is one of the most common weeds that grow wildly and abundantly throughout the tropics, especially in the moist areas, it showy bushes rapidly colonises wastelands or cleared land as their seeds are dispersed by birds [21,22,31].

Polygonum barbatum L. Syn of Persicaria barbata (L.) H. Hara (Figure 2.d). Local names e.g. Joint weed, Smart weed, Knotgrass (English), 
Mao liao (Chinese). It is native to Asia Temperate (China, Japan, Taiwan) and AsiaTropical (India, Bhutan, Nepal, Sri Lanka, Myanmar, Thailand, Vietnam, Indonesia, Malaysia, New Guinea, Philippines). It commonly found in streamsides, wet areas, water sides. Polygonum barbatum is perennial herb, rhizomatous. Stems erect, $40-90 \mathrm{~cm}$ tall, robust, pubescent, simple or branched above. Petiole 5-8 $\mathrm{mm}$, densely hispidulous; leaf blade lanceolate or elliptic-lanceolate, $7-15 \times 1.5-4 \mathrm{~cm}$, both surfaces pubescent, ocrea tubular, $1.5-2 \mathrm{~cm}$, membranous, apex truncate, cilia $1.5-2 \mathrm{~cm}$. Inflorescence terminal, spicate, erect, $4-8 \mathrm{~cm}$, several spikes aggregated and panicle-like; bracts funnel-shaped, glabrous, margin ciliate, each 3-5flowered. Pedicel short. Perianth white or greenish, 5-parted; tepals elliptic, 1.5-2 mm. Fruits achenes included in persistent perianth, black, shiny, ovoid, trigonous, 1.5-2 $\mathrm{mm}$. Polygonum barbatum is recognized as weeds in rice fields, pools, marshy grasslands, borders of ditches, and lowland-irrigated agricultural land; it dense growth may cover small ponds, irrigation ditches and small streams [18,23,32].

Debregeasia longifolia (N. L. Burman) Weddell in Candolle Syn of. Urtica longifolia, Debregeasia velutina (Figure 2.e). Local names e.g. Totongan (Sunda), Katunochchi (Tamil), Orange Wild Rhea (English). It is native to Asia temperate (China and Asia Tropical (Bangladesh, Bhutan, Cambodia, India, Indonesia, Laos, Malaysia, Myanmar, Nepal, Philippines, Sikkim, Sri Lanka, Thailand, Vietnam). It commonly found in open forest, secondary forest, forests in mountain valleys, roadsides, moist places by streams; $500-3200 \mathrm{~m}$. Debregeasia longifolia is perennial large shrub or small tree 3-6 $\mathrm{m}$ tall, dioecious or monoecious. its morphology is variable, especially in leaf shape and petiole length. Branchlets slender, reddish or purplish brown, petiole 1-4 cm; leaf blade adaxially dark green, oblong- or obovate-lanceolate, sometimes linear or narrowly ovate, papery, abaxial surface thinly greenish gray or gray-white tomentose. Inflorescences borne on current and previous years' branches, 2-4-dichotomously branched, 1$2.5 \mathrm{~cm}$; peduncle $0.3-3 \mathrm{~cm}$, glomerules globose, 3-4 $\mathrm{mm}$ in diam.; bracts triangular-ovate, ca. 1 $\mathrm{mm}$, membranous. Male flowers shortly pedicellate, obovoid in bud, 1.2-1.5 $\mathrm{mm}$ in diam.; perianth lobes 4, broadly ovate, puberulent abaxially, connate at middle, apex acute; rudimentary ovary sessile, obovoid, ca. $0.5 \mathrm{~mm}$. Female flowers sessile, obovoid, ca. $0.8 \mathrm{~mm}$; perianth tube membranous, 4-denticulate at apex. Fruit achene reddish or orange, ca. 1-1.5 $\mathrm{mm}$, enclosed by fleshy perianth and adnate to it. Debregeasia longifolia is typical plant succession on secondary forest or open forests that are undergoing recovery from damage such as after fire, so that it has well adapability to harsh conditions [18,19,].

Pteridium aquilinum (L.) Kuhn (Figure 2.f). Local name i.e. Western brackenfern (English). This species is an acidiphilous plants, cosmopolit, distributed throughout the temperate and tropical usually growing in open areas, up to $2000 \mathrm{~m}$ a.s.l. It forms a big thicket at edge of forest or recent clearing in sunny places. Pteridium aquilinum is a polycarpic geophyte; a perennial fern which reproduces by spores and widely creeping, branching underground stems, sometimes forming colonies. Rhizomes long creeping, covered with fine pale brown hairs. Stipes long, more than $1 \mathrm{~m}$ long, thick, dark brown to black in hypogeal parts, stramineous upwards, densely covered with pale brown hairs. Large compound leaves (fronds) arise directly from a deep underground rhizome that is much subdivided are 0.3-1.3 $\mathrm{m}$ high, and $15-45 \mathrm{~cm}$ long. Leaves - single, horizontally growing; broad, triangle-shaped; leaflets opposite on the main axis, the lower 2 considerably larger and twicedivided, the upper ones mainly once-divided; sub-leaflets alternate, margins lobed or wavy, edges turned under; leafstalk woody. Spores are borne in linear strips beneath the outer margins of the pinnules of fertile fronds. Pteridium aquilinum rhizomes run deeply underground, has large reserves of carbohydrate and can produce buds after fire so that become dominant covers. It is an adaptable plant, it readily colonises disturbed areas, and is favoured by fire and soil acidity. It can even be invasive in countries where it is native. Its presence reduces land productivity and adversely affects biodiversity. The plant is little affected by animals because of its toxicity $[23,22,33]$.

In Indonesia, many nature-based tourism destination areas has been disturbed by exoticinvasive species. Such exotic-invasive species becomes crucial problems [34, 35]. Based on the result of the SEAMEO BIOTROP and the State Ministry of the Environment, there are about 339 plant invasive alien species found in Indonesia [20]. The environmental impact of an alien species whether it becomes invasive at its destination depends on its biological key point, what ecological role the species may play, and on 
additional factors such as its tolerance of the gross features of the environment in the new range i.e., the degree to which the immigrant species arrives at a time when it can tolerate the environmental conditions that are being expressed currently; its direction and rate of spread; its population dynamics; its interactions with resident organisms in the new range; and the type of ecosystem it is invading [7].

Biological key point for predicting plant invasiveness based on considerable data e.g. within a genus, small genome size indicates plant invasiveness in disturbed landscapes; invasiveness of woody taxa in disturbed landscapes is associated with small seed mass, short juvenile period, and short intervals between large seed crops; vegetative forms of reproduction are an important factor, with the importance of this factor increasing with latitude; taxa belonging to genera not represented in the native flora are more likely to be invasive than alien taxa with close relatives in the native flora; plant species that depend on generalized pollinators and seed dispersers rather than specialized ones are more likely to be invasive; species with numerous, relatively small, soilstored seeds are pre-adapted for human dispersal, and hence invasion [7,9].

The pathway, along with the vector that transports the invader, are important links in an invasion. If the vector can be intercepted, then the potential invasion can be prevented. Most vectors are human-assisted transport mechanisms that move organisms across their natural barriers via global trade in agriculture, forestry, fisheries, horticulture, including tourism. Much of the responsibility for addressing tourism-related issues of invasive alien species will rest with the customs and quarantine offices in the destination countries, tourism-related agencies (both public and private) need to become more aware of the role that tourists play as vectors of invasive alien species, and take measures to educate their staff, and ultimately the tourists themselves, on the hazards of the spread of such species. Species that are potential invaders are usually not a problem where they are native species. Few governments provide significant investments to prevent export of potential invasive species, except perhaps for "domestic aliens" that are moved by people to new habitats within large nations, or between islands in island nations [7].

Numerous approaches to eradicate or control have been developed, including mechanical, chemical, biological habitat management, and a combination of methods. A holistic approach to dealing with invasive alien species is advisable, including attention to sources, pathways, interception, and rapid and thorough response at the destination. Action at the source of the potentially invasive organisms is best, because this leaves the other options available for species that nonetheless enter a new range [7].

\section{CONCLUSION}

About 11 plant species found abundantly along the corridor. Typical native plant species were dominated by Cyathea contaminans, Casuarina junghuhniana and Vaccinium varingiaefolium. They are typical shift plants of High Montane Dry Forest and Sub Alpin Forest. Three species were determined as invasive alien species i.e. Chromolaena odorata, Acacia decurrens and Blumea lacera. They grow abundantly, forms dense stands and having allelopathic effecs that prevent the establishment of other plant species, it become serious problem as it spreads rapidly via seeds and root suckers. Whereas five species were determined as native species but potential invaders i.e. Rubus moluccanus, Melastoma malabatrichum, Polygonum barbatum, Debregeasia longifolia and Pteridium aquilinum. They are mostly typical of plants succession, which have well-adaptability to harsh environments, after fire, acidic water and soil, etc., so that become dominant in the area. In some countries it has been declared as invasive species, even in countries where its native it can be invasive.

\section{ACKNOWLEDGEMENT}

Authors would like to acknowledge Achmad Suef and Adi Suprapto (Purwodadi Botanic Garden staffs) for helping authors in plants identification and characterization. Sincere thanks are also addressed to Luchman Hakim, Ph.D for all of valuable lectures, guidances and discussions regarding eco-tourism.

\section{REFERENCE}

[1]. Ministry of Environment. 2009. Fourth National Report the Convention on Biological Diversity. Biodiversity Conservation Unit. Ministry of Environment Republic of Indonesia. Available on line at http://www.cbd.int/doc/world/id/id-nr-04en.pdf 
[2]. Information on Indonesia. ASEM Development conference II: Towards an Asia-Europe partnership for sustainable development 26-27 May 2010, Yogyakarta, Indonesia. ec.europa.eu. Available online at http://ec.europa.eu/europeaid/where/asia/ regional-cooperation/support-regionalintegration/asem/documents/10.03.10_info _on_indonesia_finale_en.pdf.

[3]. Butarbutar, R. and Soemarno. 2013. Environmental Effect of Ecotourism in Indonesia. Journal of Indonesian Tourism and Development Studies 1(3): 97-107.

[4]. The International Ecotourism Society (TIES). http://www.ecotourism.org/what-isecotourism. Accessed December 2013

[5]. Sudarto, G. 1999. Ekowisata: wahana pelestarium alam, pengembangan ekonomi berkelanjutan, dan pemberdayaan masyarakat. 84pp. Yayasan Kalpataru Bahari and Yayasan KEHATI: Indonesia.

[6]. Honey, M. 2008. Ecotourism and Sustainable Development: Who Owns Paradise? (Second ed.). Washington, DC: Island Press. p. 33. ISBN 1-59726-125-4.

[7]. Global Invasive Species Programme - the Convention on International Trade in Endangered Species od Wilde Fauna and Flora (GISP-CITES). 2000. Global Strategy on Invasive Alien Species. Available on onile at http://www.cites.org/common/com/ac/16/ E16-Inf-12.pdf

[8]. Tjitrosoedirdjo, S.S. 2005. Inventory of the Invasive Alien Plant Species in Indonesia. Biotropia 25: 60-73.

[9]. Richardson, D.M. and M. Rejmanek. 2011. Trees and Shrub as Invasive Alien Species A Global Review. Diversity and Distribution 17: 788-809.

[10]. Hakim L., A.S. Leksono, D. Purwaningtyas and N. Nakagoshi. 2005. Invasive Plant Species and the Competitiveness of Wildlife Tourist Destination: A Case of Sadengan Feeding Area at Alas Purwo National Park, Indonesia. Journal of International Development and Cooperation. 12. 1:35-45

[11]. Zuhri, M and Z. Mutaqien. 2013. The Spread of Non-native Plant Species Collection of Cibodas Botanical Garden into Mt. Gede Pangrango National Park. Journal of Tropical Life Science 3(2): 74-82.

[12]. Balai Besar Konservasi Sumber Daya Alam (BBKSDA) Jawa Timur. http://www.bbksdajatim.org/kawasan/twa/ twa-ijen). Accessed December 2013
[13]. Tourism Map of Kawah ljen. http://www.eastjava.com/map/html/ijen_c rater.html?src=mappery. Accessed December 2013

[14]. Lohr, A.J., T.A. Bogaard, A. Heikens, M. R. Hendriks., S. Sumarti., M. J. Van Bergen, C.A.M. Van Gestel, N.M. Van Straaden, P.Z. Vroon and B. Widinarko. 2005. Natural Pollution Caused by the Extremely Acicid Crater Kawah ljen, East Java, Indonesia. Environmental Science and Pollution Review Articles 12(2): 89-95.

[15]. Van Hinsberg, V., K. Berlo, M. Van Bergen, A. Williams-Jones. 2010. Extreme alteration by hyperacidic brines at Kawah Ijen volcano, East Java, Indonesia: I. Textural and mineralogical imprint. Journal of Volcanology and geothermal Research. 198, 253-263.

[16]. Backer, C. A. \& R. C. Bakhuizen van den Brink, Jr. 1963-1968. Flora of Java. Groningen, Netherlands: N.V.P. Noordhoff.

[17]. Faridah Hanum I, van der Maesen LJG (eds.). 1997. Plant Resources of South-East Asia (PROSEA) No 11. Auxillary Plants. Backhuys Publishers, Leiden, the Netherlands.

[18]. Flora of China (FOC). Asteraceae. Vol 20-21; Polygonaceae. Vol 5; Fabaceae. Vol 10; Urticaceae. Vol 5. Available online at http://www.efloras.org/flora_page.aspx?flo ra_id=2.

[19]. Global Biodiversity Information Facility (GBIF). http://www.gbif.org/species/. Accessed December 2013.

[20]. South East Asia Center for Tropical Biology (SEAMEO Biotrop) and the State Ministry of the Environment. http://www.biotrop.org/database.php?act= dbias. Accessed December 2013

[21]. The Invasive Species Specialist Group (ISSG). http://www.issg.org/database/. Accessed December 2013.

[22]. Invassive Species Compendium (ISC). http://www.cabi.org/isc/default.aspx?site= 144\&page $=4066$. Accessed December 2013

[23]. Germplasm Resources Information Network (GRIN) - United States Department of Agriculture. Agricultural Research Service, Beltsville Area. http://www.ars-grin.gov/. Accessed December 2013.

[24]. Orwa, C., A. Mutua, R. Kindt, R. Jamnadass, S. Anthony. 2009. Agroforestree Database:a tree reference and selection guide version 4.0. Avalaible online at 
http://www.worldagroforestry.org/sites/tre edbs/treedatabases.asp.

[25]. Widowati, S. 2012. Kajian Potensi dan Evaluasi Penerapan Prinsip-prinsip dan Kriteria Ekowisata di Kawasan Taman Wisata Alam Kawah ljen, Desa Taman Sari, Kabupaten Banyuwangi. Thesis. Program Pascasarjana Universitas Udayana. Denpasar. Bali.

[26]. Lowe, S., M. Browne., S. Boudjelas., M. De Poorter. 2000. 100 of the World's Worst Invasive Alien Species A Selection from the Global Invasive Species Database. Published by The Invasive Species Speialist Group (ISSG) a specialist group of the Species Survival Commissin (SSC) of the World Conservasion Union (IUCN). 12 pp. Available online at www.issg.org/booklet.pdf.

[27]. Allan, H. H. B. et al. 1961. Flora of New Zealand. Available online at http://floraseries.landcareresearch.co.nz/pa ges/index.aspx.

[28]. National Herbarium of New South Wales The Royal Botanic Garden of Sidney (NHNSW-RBGS). Australia. http://plantnet.rbgsyd.nsw.gov.au/cgibin/N SWfl.pl?page=nswfl\&|v|=sp\&name=Acacia decurrens. Accessed December 2013.

[29]. Oudia, P. and R.S. Tripathi. 2000. Allelopathic effect of Kukronda (Blumea lacera L.) on linseed. Agriculture Science Digest 20(2):126-28.
[30]. Kalkman, C. 1984. The genus Rubus (Rosaceae) in Malesia. 2. The subgenus Malachobatus. Blumea 29:346. Available online at http://www.ingentaconnect.com/ content/nhn/blumea

[31]. Mohd. Joffry, S., N.J. Yob, M.S. Rofiee, M.M.R.M. Affandi, Z. Suhaili, F. Othman, A.M. Akim, M.N.M. Desa and Z.A. Zakaria. 2012. Melastoma malabathricum (L.) Smith Ethnomeicinal Uses, Chemical Constituents, and Pharmacological Properties: A review. Hindawi Publishing Corporation. EvidenceBased Complementary and Alternative Medicine Volume 2012, Article ID 258434, $48 \mathrm{p}$.

[32]. Singh, C.M., N.N. Angiras and S. Kumar. 1996. Weeds Management. M.D. Publications Pvt. Ltd. 152 p.

[33].The Royal Botanic Garden of Edinburgh (RBGE). Edinburgh-United Kingdom. http://rbg-web2.rbge.org.uk/. Accessed December 2013.

[34]. Hakim, L. 2011. Cultural Landscapes of the Tengger Highland, East Java. In: S.-K. Hong, et al. (eds.) Landscape Ecology in Asian Cultures. Ecological Research Monographs, Part I, pp: 69-82, Springer Verlag, Tokyo.

[35]. Hakim, L., Soemarno, Hong, S.K. 2012. Challenges for conserving biodiversity and developing sustainable island tourism in North Sulawesi Province, Indonesia. Journal of Ecology and Field Biology. 35 (2): 61-71 